\title{
ORIGINAL
}

\section{Continuous Glycerolysis of Fat by Lipase in Microporous Hydrophobic Membrane Bioreactor*}

\author{
Tsuneo YAMANE**, Mohammad Mozammel HoQ, Sumiyo ITOH, and Shoichi SHIMizU \\ Laboratory of Bioreaction Engineering, Department of Food Science and Technology, \\ School of Agriculture, Nagoya Univesirty, (Chikusa-ku, Nagoya)
}

The continuous glycerolysis of olive oil by Pseudomonas fluorescens lipase was performed at $40^{\circ} \mathrm{C}$ in a microporous hydrophobic membrane bioreactor previously developed by the authors. Two kinds of flat membranes, one made of polypropylene and the other made of poly (tetrafluoroethylene) (Teflon), were used. The olive oil was fed into the fat compartment on one side of the membrane and the product was obtained from the outlet in a single phase. The glycerol containing small amounts of water and enzyme was fed in to the opposite side of the membrane in the bioreactor and recycled to the glycerol reservoir. After $9 \sim 20$ hours of a transient state, steady states were attained. The enzyme concentration in the glycerol phase did not affect the composition of the outlet product. Teflon membrane gave a somewhat higher conversion than the polypropylene membrane. The conversion increased with a decrease in flow rate, approaching the one at chemical equilibrium. The conversion was highly restricted at lower water concentrations. At water concentrations higher than $4 \%$, free fatty acid was produced. The half life of the enzyme during the continuous reaction was about 3 weeks.

\section{Introduction}

In the preceding article, some characteristics of fat glycerolysis by lipase were elucidated ${ }^{1}$. It was found out that the water concentration was most influential not only for the reaction rate but also for the composition at the che= mical equilibrium. The glycerolysis reaction was carried out batchwise as an emulsion system in a small agitated vessel using free enzyme. This reaction system was convenient to get a number of data concerning the effects of various factors on the fat glycerolysis. However, it has following disadvantages as an industrial scale system.

1) Batch operation has much less volumetric productivity than continuous one.

2) Emulsion system needs stirring at high speed. Futhermore, after the reaction has finished, the separation of emulsified oily products needs powerful centrifugation and/or solvent extraction.

* Bioreactor for Enzymic Reaction of Fat and Fatty Acid Derivatives, Part VIII***.

** To whom all correspondence should be add= ressed.

*** Part I-VII, see Ref. 1) 7).
3) The reaction system of free lipase plus emulsified substrate is uneconomical because it is impossible to reuse the enzyme.

Recently the authors have developed a bioreactor system which is suitable for the bioconversion of fat and fatty acid derivatives. The bioreactor utilizes a microporous hydro= phobic membrane, either in flat or in hollow fiber module. With the membrane bioreactor, the authors studied continuous hydrolysis of $\mathrm{fat}^{2) \sim 5}$ and continuous synthesis of glycerides from fatty acid and glycerol ${ }^{6,7)}$.

Since it is possible to overcome most of the aforementioned disadvantages inherent in the reaction system of emulsion plus free enzyme, the authors have attempted continuous glyce= rolysis of fat by lipase in the microporous hydrophobic membrane bioreactor. Experimental data concerning some factors governing the reaction will be reported in this paper.

\section{Materials and Methods}

\subsection{Lipase and Chemicals}

Pseudomonas fluorescens lipase, Lipase P, supplied by Amano Pharmaceutical Co., Ltd., Nagoya, was used throughout the experiments. Its hydrolytic activity, as determined by the 
olive oil emulsion method described previously was about 29 units/mg.

Olive oil having a saponification value of 190 , purchased from Wako Pure Chemical Industries Co., Ltd., Osaka, was used without dilution by any solvent throughout the experiments. In the long term continuous glycerolysis reaction the olive oil dehydrated by molecular sieve particles (Type $4 \mathrm{~A} \mathrm{XH-5,} \mathrm{Union} \mathrm{Showa} \mathrm{Co.,}$ Ltd., Tokyo) was used. Glycerol of $99 \%$ purity from Nippon Oil and Fats Co., Ltd., Amagas saki Works, Hyogo Prefecture, was used.

\subsection{Configuration of the Membrane Bioreactor}

The microporous hydrophobic membrane bioreactor used was the same one unit of plate type dialyzer as used in the previous study' ${ }^{2}$. Two kinds of microporous hydrophobic flat membrane were used, one made of polypropylene and the other made of poly (tetrafluoroethylene) (Teflon). The membrane made of polypropylene (Juragurd 2500, Polyplastic Co., Ltd., Tokyo) was $25 \mu \mathrm{m}$ thick and its void fraction was $55 \%$. The micropores of the polypropylene film were elliptically shaped pores with maximum pore diameter of $0.4 \mu \mathrm{m}$. The membrane made of poly(tetrafluoroethylene) (Japan Gore-Tex Inc., Tokyo) was $15 \mu \mathrm{m}$ thick and its void fraction was $70 \%$ and the maximum pore diameter was $0.4 \mu \mathrm{m}$.

The setup of the microporous hydrophobic membrane bioreactor was the same as used in the previous work ${ }^{6}$. The glycerol-water-lipase solution was passed through the narrow com $=$ partment between two sheets of membrane, while olive oil was passed on the opposite side of the membrane in the grooves of the plates.

Fig.-1 shows the neighborhood of the membrane where micropores are drawn very schematically. Owing to the hydrophobic nature of the membrane, olive oil penetrated readily the

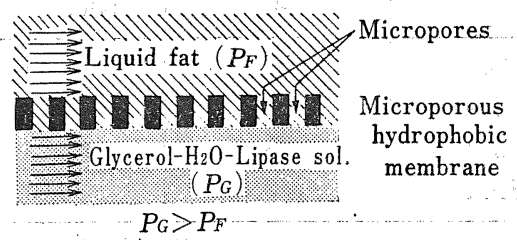

Micropores are drawn very schematically.

Fig.-1 The neighborhood of the membrane.

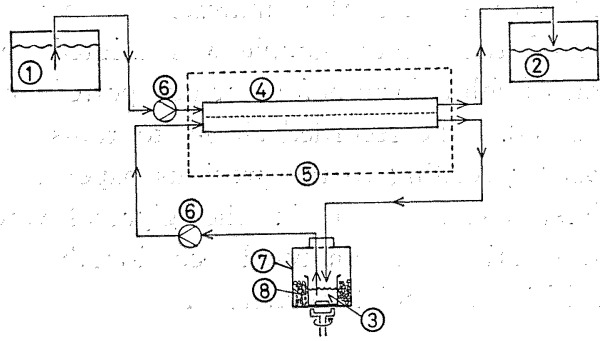

1. liquid fat; 2 . product; 3 . glycerol-waterlipase solution; 4. membrane bioreactor; 5 . thermostated water bath; 6. pump; 7 . desic= cator; 8. silica gel.

Fig.-2 Process flow diagram of the continuous glycerolysis reaction sestem.

micropores while glycerol-water-lipase solution could not. However, because of the high viscosity of the glycerol-water-lipase solution, the pressure of this solution was a little greater than that of olive oil, which did not allow olive oil to pass through the membrane. Thus, the olive oil came in contact with glycerol-water= lipase solution as shown in Fig.-1. The glyce= rolysis reaction took place at the glycerol-side surface of the membrane. The product diffused back into the bulk flow of the olive oil phase.

A process flow diagram of the reaction system is shown in Fig.-2. Olive oil was fed at a definite flow rate into the bioreactor with two reciprocal (plunger) pumps (Micro pump, Model SP-100, Sibata Chemical Apparatus Manufac= turing Co., Ltd., Tokyo). Each pump fed olive oil to each fat compartment with the same flow rate. The product formed was obtained from the outlet in a single phase. That is, the product was never mixed with the glycerol-wa= ter-lipase solution and was collected in a fracs tion collector. The glycerol-water-lipase solution in a beaker which was placed in a desiccator was fed at the flow rate of $7.2 \mathrm{ml} \cdot \mathrm{h}^{-1}$ with a peristaltic pump (Minipuls 2, Gilson France SA, Villiers Le Bel, France), and the solution from the outlet was recycled back into the beaker. In the desiccator were placed silica gel particles around the beaker to prevent moisture absorption into the glycerol-water-lipase solus tion. The membrane bioreactor was placed in a thermostated water bath $\left(40^{\circ} \mathrm{C}\right)$.

\subsection{Analytical Procedures}

The composition of the product was deter= 
mined with a TLC/FID analyzer ${ }^{1)}$. Thirty to $50 \mathrm{mg}$ of the output sample was diluted with $1.0 \mathrm{ml}$ of chloroform before being spotted on a quartz rod. The recorded chromatograms were analyzed according to the previous paper ${ }^{1)}$.

Water concentration in the glycerol-waterlipase solution was analyzed occasionally with a Carl-Fischer moisture meter ${ }^{1}$.

\section{Results and Discussion}

\subsection{Typical Time Course}

Fig. -3 shows a typical time course of the continuous glycerolysis of olive oil by Pseudo= monas fluorescens lipase. After $9 \mathrm{~h}$ transient state from the start of the continuous operation, a steady state was attained. The length of transient state depended on the flow rate of the oil : the higher the flow rate, the shorter the transient state. During the continuous operation, the water concentration in the glys cerol phase increased a little, probably because the water dissolved in the olive oil transferred to the glycerol phase through the microporous membrane in the bioreactor. The water cono centration in the olive oil was $0.10 \%$, which was higher than the equilibrium value in the olive oil phase corresponding to $3.0 \%$ of water in the phase of the glycerol-water-lipase soluc tion $^{1)}$ : Therefore, water transferred from the oil phase to the glycerol phase to approach the thermodynamical distribution. It should be noted here that water is neither liberated nor consumed during the glycerolysis reaction.

\subsection{Effect of Enzyme Concentration in}

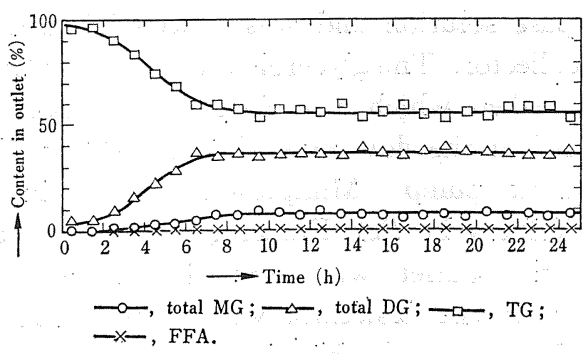

The enzyme concentration was 190 units/gglycerol, the water concentration in the glycerol phase was $2.8 \sim 2.9 \%$ and the flow rate of olive oil was $2.5 \mathrm{ml} \cdot \mathrm{h}^{-1}$.

Fig.-3 A typical time course of the cono tinuous glycerolysis reaction.

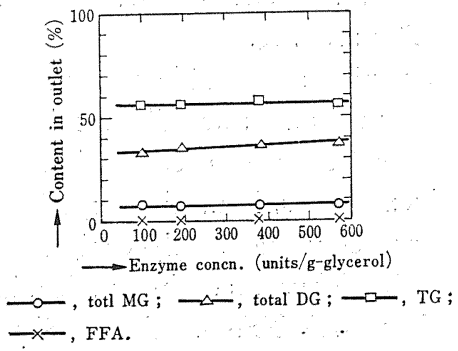

The water concentration was $2.8 \sim 3.2 \%$ and the flow rate of olive oil was $2.5 \mathrm{ml} \cdot \mathrm{h}^{-1}$.

Fig. -4 Effect of enzyme concentration in the glycerol solution on the composition of the outlet.

\section{Glycerol}

Enzyme concentration in the glycerol phase (in the range of 100 600 units/g-glycerol) did not affect the composition of the outlet product as shown in Fig.-4. It is quite conceivable that the conversion will decrease when the enzyme concentration is lower than the values shown in Fig. -4. In order to know whether the molecular diffusion of the oily como pounds in the micropores limited the overall glycerolysis reaction, an experiment was carried out using a thinner membrane made of Teflon. The results shown in Table-1 indicates that the thinner membrane improved the conversion slightly. Thus, the molecular diffusion affected a little the overall reaction rate. However, further detailed studies with respect to both diffusion and enzyme-adsorption phenomena are needed to know the rate-limiting step. Differs ences in pore size, void fraction, thickness and material of the two kinds of membrane must be taken into consideration.

\subsection{Effect of Flow Rate on Conversion}

Table-1 Comparison of microporous polypros pylene and poly (tetrafluoroethylene) membranes.

\begin{tabular}{c|c|c}
\hline Component & $\begin{array}{c}\text { Polypropylene } \\
(\%)\end{array}$ & $\begin{array}{c}\text { poly(tetrafluoros } \\
\text { ethylene)'(\%) }\end{array}$ \\
\hline TG & 57 & 49 \\
Total DG & 36 & 41 \\
Total MG & 8 & 10 \\
FFA & 0 & 0 \\
\hline
\end{tabular}

The water concetration was $2.8 \%$, the enzyme concentration was 190 units/g-glycerol and the flow rate of olive oil was $2.5 \mathrm{ml} \cdot \mathrm{h}^{-1}$. 


\section{and Composion of Outlet}

The effect of the flow rate of olive oil on the conversion and composition was investigated. The results are shown in Fig. -5 . The cons version increased with decrease in the flow rates because of longer residence times of fat in the bioreactor. The values of the conversion and composition at the lowest flow rate were close to the ones at the chemical equilibrium which was attained in the batch reaction ${ }^{1}$.

\subsection{Effect of Water Concentration on}

Conversion and Composition of Outlet

The effect of the water concentration in the glycerol-water-lipase solution on the conversion and composition of the outlet was investigated by varying the water concentration in the ranges indicated in Fig.-6. Alike in the batch reacs

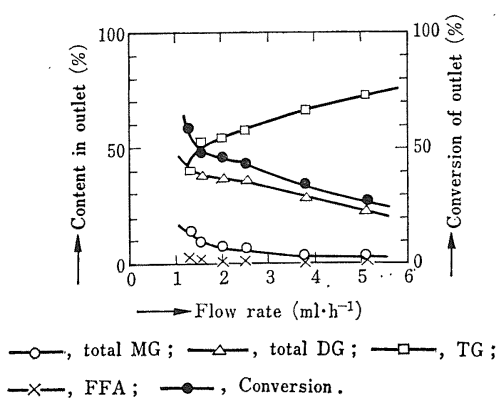

The enzyme concentration was 190 units/gglycerol and the water concentration in the glycerol phase was $2.8 \sim 3.0 \%$.

Fig. -5 Effect of the flow rate of olive oil on the conversion and composition of the oultet product.

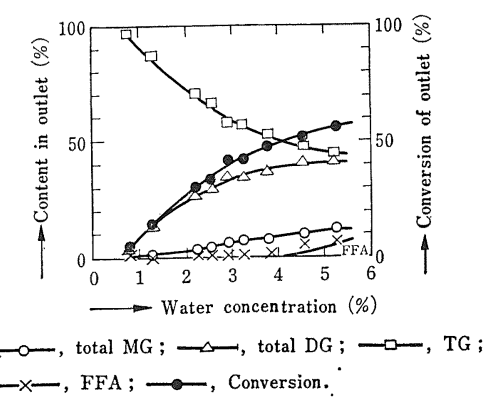

The enzyme concentration was 190 units/gglycerol and the flow rate of olive oil was $2.5 \mathrm{ml} \cdot \mathrm{h}^{-1}$.

Fig.-6 Effect of the water concentration in the glycerol phase on the conversion and composition of the outlet pros duct.

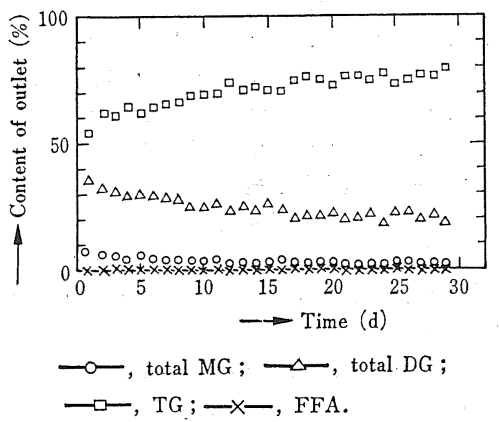

The enzyme and water concentrations in the glycerol phase were 190 units/gglycerol and 3.2 4.1\%, respectively. The flow rate of olive oil was 2.5 $\mathrm{ml} \cdot \mathrm{h}^{-1}$.

Fig. -7 Time course of the composition in the long term continuous operation.

tions $^{1)}$ the conversion was highly restricted at lower water concentrations, probably because some amount of water was required for the enzyme to exhibit its glycerolysis activity. At water concentration higher than $4 \%$, free fatty acid (FFA) was produced because the hydro= lysis reaction became significant.

Fig.-6 suggests that the water concentration should be kept at $4 \%$ strictly to obtain the products without FFA and yet to achieve the highest conversion.

\subsection{Operational Stability of Lipase}

A long term continuous reaction was carried out to know the operational stability of the lipase. The result shown in Fig. -7 indicates that the half-life of the enzyme during the cono tinuous reaction was about 3 weeks. Although the conversion decreased gradually in this experiment because of the unvaried feed rate of fat, it is possible to keep the conversion constant if one decreases the feed rate of fat gradually with time, adjusting it to the loss of the enzyme activity. To obtain more prolonged high conversion, experimentation at lower tem $=$ perature or with more thermostable lipase may be preferable.

(Received March 6, 1986)

\section{References}

1) T. Yamane, M.M. Hoq, S. Itoh, and S. Shic mizu, J. Jpn. Oil Chem. Soc. (Yukagaku), 35, 625 (1986), the preceeding article.

2) M.M. Hoq, T. Yamane, S. Shimizu, T. Fu= nada, and S. Ishida, J. Am. Oil Chem. Soc., 
62, 1016 (1985):

3) M.M. Hoq, M. Koike, T. Yamane, and S. Shimizu, Agric. Biol. Chem., 49, 3171 (1985).

4) M.M. Hoq, T. Yamane, and S. Shimizu, Enz. Microb. Technol., 8, 237 (1986).

5) T. Yamane, M.M. Hoq, and S. Shimizu, Yu= kagaku, 35, 10 (1986):

6) M.M. Hoq, T. Yamane, S. Shimizu, T. Fus nada, and S. Ishida, J. Am. Oil Chem. Soc., 61, 776 (1984).

7) M.M. Hoq, T. Tagami, T. Yamane, and S. Shimizu, Agric. Biol. Chem., 49, 335 (1985).

微孔性疎水性薄膜型バイオリアクター を用いたリパーゼによる油脂の連続 グリセロリシス*

山根恒夫・モハメド モザメル ホック。 伊藤純代・清水祥一

名古屋大学農学部食品工業化学科生物反応工学講座 （名古屋市千種区不老町 1)
Pseudomonas fluorescens 産生のリパーゼによるオ リブ油の連続グリセロリシス反応を, 著者らが以前開発 した微孔性疎水性薄膜型バイオリアクターを用いて， $40^{\circ} \mathrm{C}$ で実施した。平膜として，ポリプロピレン膜とポ リ四フッ化エチレン（テフロン）膜を調べた。オリブ油 を平膜の一方の側に供給し, 生成物は出口より他相を含 まない単相状態で得られた。一方, 小量の水分と酵素を 含むグリセリンを平膜の反対側に供給し, 流出液はグリ セリン貯槽へ戻し再循環した。9 20h の遷移状態の 後, 定常状態が得られた。グリセリン中の酵素濃度を変 えても，生成物中の組成は変化しなかった。テフロン膜 はポリプロピレン膜より少し高い反応率を与えた。オリ ブ油の流量を減少させると反応率は増大し，化学平衡に 近づいた。低水分では反応率はきわめて低かった。4\% 以上の水分では, 遊離脂肪酸の生成が見られた。酵素の 半減期は約 3 週間であった。

* 油脂関連化合物の酵素的変換のためのバイオリアクター （第 8 報） 